\title{
A CONCEPTUAL FRAMEWORK OF DISTRIBUTIVE JUSTICE IN ISLAMIC ECONOMICS
}

\author{
Shafinah Begum Abdul Rahim \\ Universiti Malaysia Sarawak
}

\begin{abstract}
Distributive justice is an aspect immensely debated in studies of philosophy, political, behavioural and social sciences both in mainstream or Islam. Given its increasing relevance to the global village we share and the intensity of socio-economic problems invariably related to the distribution of resources amongst us, this work is aimed at adding value through a deeper understanding and appreciation of justice placed by the Syariah in all domains of of our economic lives. The existing works within this area appear to lean mostly towards redistributive mechanisms available in the revealed knowledge. Hence a comprehensive analysis of the notion of distributive justice from the theoretical level translated into practical terms is expected to contribute significantly to policymakers committed towards finding permanent solutions to economic problems especially in the Muslim world. It is a modest yet serious attempt to bridge the gap between distributive justice in letter and spirit as clearly ordained in the Holy Quran. The entire analysis is based on critical reviews and appraisals of the all relevant literary on distributive justice in Islamic Economics. The final product is a conceptual framework that can be used as a blueprint in establishing the notion of justice in the distribution of economic resources, i.e. income and wealth as aspired by the Syariah.
\end{abstract}

Keywords: amanah, distribution, justice, needs, rights

\section{INTRODUCTION}

Distributive Justice has been one of the key aspects immensely debated in mainstream economics and can be traced back from the times of Greek philosophers, Aristotle and Plato who steadfastly held that the notion of distributive justice was a form of justice, basically referring to the assignment of benefits and burdens, those who are equal in relevant ways to be treated equally and those who are unequal in relevant ways to be treated unequally in proportion to their inequality. Generally it concerns what some consider to be 'socially just' with respect to the allocation of goods in a society.

Distributive justice is often considered not to belong to the scope of economics, but remains as important in economic literature that addresses normative issues in social and economic justice. A variety of economic theories and approaches provide many insights in these matters, including the theory of inequality and poverty measurement, welfare economics, the theory of social 
choice, the theory of bargaining and of cooperative games, and the theory of fair allocation, to name a few.

Despite its powerful affect on the standards of living of the masses, the role of distributive justice is often neglected due to the overlooking of distortions in distributional processes. Although some may well argue that social justice had always been a great concern as early as the times of Prophet Muhammad (S.A.W), the concept of distributive justice per se only came about as an independent economic issue with the increased socio-economic problems in the Muslim world. Distribution is an important economic issue, given the present state of economic inequalities among and within many Muslim countries. According to Heidari (2007) distributive justice in Islam is completely established in a divine framework, and therefore the main duty of Muslim scholars and scientists is to discover the pure rules of justice from Quran and Sunna and to adjust them to the prevailing circumstances of the modern era.

Naturally, Islam demands for socioeconomic inequalities to be minimized through fair distributional systems of resources, factor payments and transfer payments. Reports by the United Nations Department of Economic and Social Affairs regularly state that the income-related inequalities, particularly in capital ownership and access to benefits is growing worldwide, suggesting regression in social justice. World leaders dread that the failure to actively pursue justice in all its dimensions is feared to translate into de facto acceptance of a future marred by violence, repression and chaos.

The 2013 Key Socioeconomic Statistics on IDB Members Countries provides a summary of a wide range of economic indicators overtime. Interestingly, a lower GINI index, (a standard measure of the extent to which the distribution of income or consumption expenditure) among households within an economy, does not essentially mean that the gap between the rich and the poor is acceptable. As a matter of fact, the information on the Human Development Index (HDI) reveals the degree of distribution or a lack of it in a much broader scale. Table 1 provides an overview of the recent estimates of the above mentioned indexes and their ranking within the group for selective Asian OIC Countries:

\begin{tabular}{|l|l|l|l|l|}
\hline Countries & Bangladesh & Indonesia & Malaysia & Maldives \\
\hline Gini Coeffient & 32.1 & 34.0 & 46.2 & 37.4 \\
\hline HDI/ Ranking & $0.52 / 146$ & $0.63 / 121$ & $0.77 / 64$ & $0.69 / 104$ \\
\hline I-HDI $^{1}$ & $0.43 / 32$ & $0.58 / 18$ & $0.77 / 6$ & $0.58 / 20$ \\
\hline
\end{tabular}

${ }^{1}$ MB Hendrie Anto (2011). Introducing an Islamic Human Development Index (I-HDI) to Measure Development in OIC Countries, Islamic Economic Studies, Vol. 19, No. 2, pg. 90. 
In short, statistical evidences raise the need to critically reconsider the existing theoretical models of the dominant mainstream economics and suggests for an alternative framework that might produce a desirable economic distribution rooted on the notion of justice. This study attempts to demonstrate that there is more to ensuring a just distribution in an economy than meets the eye. From the perspective of Islamic Economics, distributive justice is to be emphasized at all stages of production in meeting objectives of the Syariah, because the distributive justice promoted by Islam deems certain guiding principles as rules to any form of distribution to be recognized as just.

To Muslim theologians and philosophers, justice is an abstract and idealist concept. They made no serious attempt to view it from a positive concept and analyze it from the existing social conditions. Abu Bakr al-Turtushi (520/1127), Najm al-Din al-Tawfi (716/1316) and Ibn Taymiyah (728/1325) while remaining faithful to Revelation, employed a form of inductive method which reached its full development in the writings of Ibn Khaldun (806/1408). Turtushi considered justice as the very foundation of polity, the 'foundation of foundations.2 Al-Ghazali (450/1058) discusses the concept of justice from several dimensions, focusing mainly on distributive justice. He emphasized that for justice to prevail, the state must remove poverty and distress in the society. Mawdudi (1903-1979) however claimed that the disregard of the role of moral values in the efficient and equitable allocation and distribution of scarce resources may be the reason for the lack of emphasis placed on the reform of the individuals as market players.

Contemporary Muslim scholars, Umar Chapra (1981) and Nejatullah Siddiqui (1986) initiated creative ways to incorporate the relevance of justice in distributive functions. They began to steer attention towards distribution in Islamic scholarship. In discussing distributional issues in Islam, the literature is limited to studies related to income inequalities. The absence of academic works in the formulation of a theory of Distributive Justice, gives the main purpose to the current mission. The lack of preference to develop an Islamic theory of distributive justice could be attributed to the normative nature of the issue in itself.

\section{ECONOMIC VISION OF DISTRIBUTION IN ISLAM}

The distribution system of Islam is grounded in a general ideological base that Allah is the Only Real Owner. As for man, he is not more than a deputizing vicegerent. He can only manage what he owns within certain limits, specified by Allah.

\footnotetext{
${ }^{2}$ The Islamic Conception of Justice by Majid Khadduri (1984)
} 
"And certainly you have come to Us alone as We created you at first, and you have left behind your backs the things which We gave you, and We do not see with you your intercessors about whom you asserted that they were (Allah's) associates in respect to you; certainly the ties between you are now cut off and what you asserted is gone from you." (6:95).

Islam approaches distribution from the single most important axiom, Tawheed. The implications of the concept of Unity of God are twofold; Absolute ownership rest with the Creator and thus all men have equal rights over His bounties.

Say: "In Whose Hand is the absolute ownership and dominion of all things, and He protects and grants asylum, whereas against Him no asylum is available, and Himself never needs protection? (Tell me,) if you have any knowledge."(23:88).

Is it they who would portion out the Mercy of thy Lord? It is We Who portion out between them their livelihood in the life of this world: and We raise some of them above others in ranks, so that some may command work from others. But the Mercy of thy Lord is better than the [wealth] which they amass. (43:32).

The opposite of distribution is hoarding, an act of accumulating resources beyond one's genuine needs and sufficiency. The Quran dictates an entire surah on this matter alone.

The mutual rivalry for piling up (the good things of this world) diverts you (from the more serious things), Until ye visit the graves. But nay, ye soon shall know (the reality). Again, ye soon shall know! Nay, were ye to know with certainty of mind, (ye would beware!) Ye shall certainly see Hell-Fire! Again, ye shall see it with certainty of sight!Then, shall ye be questioned that Day about the joy (ye indulged in!). (102:1-8).

But, Allah (S.W.T) says, "Hath exalted some of you in rank above others" (7:166). This indicates that equality is not absolute and there are bound to be some form of disparity even on the basis of taqwa (God consciousness). The issue here is that, realizing one's prosperity, Muslims are asked to remember those vested with less and consume in ways that can benefit themselves and others. In yet another verse, Allah commands us to give the wealth of God which He has given us.

They are in varying gardens in the sight of Allah, and Allah sees well all that they do. (3:163).

The second object of the Islamic system of the distribution of wealth is to enable everyone to get what is rightfully his. However, in Islam the concept and criteria of this right is somewhat different from other systems of economy. 
Under materialistic economic systems, there is only one way of acquiring the right to "wealth", and that is a direct participation in the process of production. On the contrary, the basic principle of Islam in this respect is that 'wealth' is, in principle the property, of Allah Himself and He alone can lay down the rules as to how it is to be acquired and used. So according to the Islamic perspective, not only those who have directly participated in the production of wealth but also those to whom Allah has made it obligatory upon others to help, are the legitimate sharers in wealth.

And those in whose wealth is a recognized right. (70:24).

That man can have nothing but what he strives for. (53:39).

And in their wealth and possessions [was remembered] the right of the [needy,] him who asked, and him who [for some reason] was prevented [from asking]. (51:19).

According to Sadr (1982) the first step to end the contradictions in the economic structure of society begins with the distribution of economic resources among people. He adds that the foremost form of economic wealth is the natural resources of the environment and an unjust distribution of it begins with the problem of their ownership. He developed the theory of distribution of natural resources at two stages: preproduction and postproduction stages, or what he calls primary wealth and secondary wealth, respectively. ${ }^{3}$

Allah enlarges the sustenance [which He gives] to whichever of His servants He pleases; and He [similarly] grants by [strict] measure, [as He pleases]: for Allah has full knowledge of all things. (29:62).

Coincidently, resource distribution was the first issue to be resolved by Prophet Muhammad (S.A.W) and had attributed his presence as being the source of establishing a fair and just society. To understand the different norms of allocation during the periods of Prophet himself, and later his two successors, namely Abu Bakar and Umar, he highlights the relevance of changed social realities of the Arabs throughout. While need was the main criteria of concern in the times of the Prophet, Khalifah Abu Bakar adopted the rule of equality and Khalifah Umar the on the basis of merit of the recipient. Undoubtedly, the standards of distribution were moderated by factors such as the availability of resources and the intensity of needs and desert. ${ }^{4}$

Mabid Al-Jarhi (1985) attempted to construct a macro-distribution model for an

${ }^{3}$ AlSadr, "alNazariyyah al'Islamiyyah litawzi' almasadir altabi'iyyah" (Islamic Theory of Distribution of Natural Resources) in Ikhtarnalak (Beirut: Dar alZahra', 1982), 136137.

${ }^{4}$ Distributive Justice:The Islamic Perspective Intellectual Discourse, Vol 8, No 2, 159 172. 
Islamic Economy. Supposing that Muslims, are propertied, to varying degrees, he implies two essential propositions; first, that the study of distribution is inseparable from that of redistribution and secondly, that the saving behavior between the capitalists and labourers being immaterial. As the division of social class is theoretically meaningless in a hypothetical Islamic economy, in general the society is seen as capital holders (salaried predominantly). The significances of nisab and the market-order of an Islamic financial system are highlighted. Based on the premise that the prevailing distribution of wealth could deviate from the most desirable level, the Syariah provides for means to modify people's behavior towards saving and investment, unlike in the Western models.

M. A. Haneef (1995), In the Contemporary Islamic Economic Thought: A Selected Comparative Analysis had carefully appraised the views of six Muslim scholars, on namely five areas, one of which is distribution. The differing opinions of these prudently chosen trained economists and Islamic jurists are provided by the summary below:

Table 2: Selective reviews of Muslim scholars on Distribution

\begin{tabular}{|l|l|l|}
\hline \multicolumn{1}{|c|}{ Scholars } & \multicolumn{1}{c|}{ Central Thesis } & \multicolumn{1}{c|}{ Supporting Arguments } \\
\hline M.A. Mannan & $\begin{array}{l}\text { Should determine produc- } \\
\text { tion and consumption }\end{array}$ & $\begin{array}{l}\text { Inequalities permissible due to } \\
\text { differing endowments but insist } \\
\text { on equal opportunity to all }\end{array}$ \\
\hline $\begin{array}{l}\text { M. Nejatullah } \\
\text { Siddiqi }\end{array}$ & $\begin{array}{l}\text { Divides it to pre and post } \\
\text { production. }\end{array}$ & $\begin{array}{l}\text { Emphasis on initial distribution } \\
\text { of resources and societal needs. }\end{array}$ \\
\hline $\begin{array}{l}\text { Syed N. Haider } \\
\text { Naqvi }\end{array}$ & $\begin{array}{l}\text { Dominant role of the State } \\
\text { in redistributive schemes }\end{array}$ & Concept of Ownership \\
\hline Monzer Kahf & $\begin{array}{l}\text { Justice in functional distri- } \\
\text { bution }\end{array}$ & $\begin{array}{l}\text { Market mechanism in factor } \\
\text { pricing }\end{array}$ \\
\hline $\begin{array}{l}\text { Sayyid Muhamad } \\
\text { Taleghani }\end{array}$ & $\begin{array}{l}\text { Adds the third element of } \\
\text { redistribution while main- } \\
\text { taining natural resources to } \\
\text { common property. }\end{array}$ & $\begin{array}{l}\text { Work and need as the core basis } \\
\text { of distribution. }\end{array}$ \\
\hline $\begin{array}{l}\text { Muhamad Baqir } \\
\text { Al-Sadr }\end{array}$ & $\begin{array}{l}\text { Work as basis for usufruct } \\
\text { rights }\end{array}$ & $\begin{array}{l}\text { Economic labour as a source of } \\
\text { ownership }\end{array}$ \\
\hline
\end{tabular}

While each of the scholars' approaches the issue of distribution from a diverse starting point, the validity of need and labour as a pre-requisite to a just distribution is unmistakably evident. A majority of them also balance the call for redistribution with the demand for equal initial opportunity. 


\section{THE ISLAMIC DISCOURSE ON DISTRIBUTIVE JUSTICE}

In recent years, distributive justice has emerged as an important topic among Muslim scholars of Islamic Economics. Underlying these discussions is the strong Islamic ethics of providing basic subsistence, for the most disadvantaged members of society. This involves individual obligation and personal piety as well as a state responsibility for social welfare. The ethical principle is formalized as one of the five pillars of faith in the form of tax of surplus wealth known as zakat.

Zubair Hassan (1988) stands firm on the idea that distributive justice from an Islamic perspective is a matter of integrated implementation of the interrelated mechanisms available in the system. He claims that one of the reason for the world to be torn between different economic systems is because of the problem of having to decide whether economic freedom or distributional equity should be given the highest priority in the social schemes of things. Seemingly, the differences in opinion on the appropriateness of a variable as an action base, the view of an appropriate equitable distribution and the extent of combining equity with the pursuit of other policy goals remains a challenge. the concept of 'amanah' is the foundation of equity in his model. From an economic stance, it refers to the 'appropriate' dispense of productive resources such as opportunities (entry and other technical support) based on the needs of the recipient.

Islamic Distributive Justice: A Concise Statement by Islahi (1992) was an attempt to provide a comprehensive list of provisions in regard to institutional arrangement of Islam for distributive justice. As compared to production and functional distribution which are left to the mutual agreement of the producing agents with the emphasis on justice, fair play and honesty in deciding the remunerations, Islam's focus is on personal distribution or the redistributional aspects of our economy.

Heidari (2007) reminds that Islam's overemphasis on the ethical concepts of altruism, benevolence, philanthropy together with its forewarning against wasteful consumption and concentration of income and wealth to be the key elements of distribution in Islam. He summarizes the main schemes of distributive justice in Islam to include an institutional approach, multiplicity and decentralized structure of redistributive measures, and hierarchal to lend flexibility to the system. Given the divine nature of the framework, the task of Islamic scholars and scientists is to discover the pure rules of justice from Quran and Sunnah and to adjust them to the prevailing circumstances of the modern era, he adds. 


\section{STUDIES RELATED TO DISTRIBUTION IN THE PRE- PRODUCTION PHASE}

In an Islamic system, one may look at the role of government with reference to the performance of markets, the provision of public goods and environmental care. It is expected to react promptly towards market failures at a minimal cost to the society. Siddiqui (1986) in his discussion on the guaranteeing of a minimum level of living in an Islamic State begins with the Syariah's requirement for every individual to strive to fulfill their lives basic needs. He emphasizes living for a purpose, which inevitably demands efficiency and dignity. According to the scholar, the list of needs and the extent to which each need should be fulfilled is a matter of economic conditions of a particular society. The guarantee of need fulfillment or the right to livelihood follows logically from the Islamic view of the following;

a) Life as a test,

Blessed is He in whose hand is dominion, and He is over all things competent. [He] who created death and life to test you [as to] which of you is best in deed-and He is the Exalted in Might, the Forgiving. (67:1-2)

b) The status of men and women as vicegerents, And We have certainly honored the children of Adam and carried them on the land and sea and provided for them of the good things and preferred them over much of what We have created, with [definite] preference. (17:70)

c) Their being distinguished from other creatures by a special dignity, And We have certainly established you upon the earth and made for you therein ways of livelihood. Little are you grateful. (7:10)

d) From the fact that the universe has been well provisioned to sustain human life; and from the cooperative nature of the Islamic society,

The believing men and believing women are allies of one another. They enjoin what is right and forbid what is wrong and establish prayer and give zakah and obey Allah and His Messenger. Those - Allah will have mercy upon them. Indeed, Allah is Exalted in Might and Wise. (9:71)

The syariah guarantees equality of all Muslims before law, while the Quranic enjoinments and legal penalties prescribed by Islamic law enables the state to enforce the administration of justice.

O mankind! We created you from a single (pair) of a male and a female, and made you into nations and tribes, that ye may know each other (not that ye may despise (each other). Verily the most honoured of you in the sight of Allah is (he who is) the most righteous of you. And Allah has full knowledge and is well acquainted (with all things). (49:13). 
Chapra (2007) in his Guarantee of Satisfaction of Fundamental Needs, states that one of the essential goals of Islam is to be a blessing for mankind and an indispensable requisite for being a blessing is to ensure the wellbeing of all people.

And We have not sent you, [O Muhammad], except as a mercy to the worlds. (21:107).

In conclusion, need based rights and the significance of ownership play a strategic role in the distribution of economic resources at the pre-production stage of an Islamic economy.

\section{STUDIES RELATED TO THE POST-PRODUCTION PHASE}

In recent years there has been a universal rediscovery of the market and a greater appreciation of the allocative role of the market. Consequently, the role of the state is changing from one that competes with the market to one that augments and improves its working.

Sadeq (1989) states two normative principles of factor pricing in Islam; justice and scarcity. It is ordained that a person receives what he works for or that the price for his labour corresponds with his contribution.

And in no wise covet those things in which Allah Hath bestowed His gifts More freely on some of you than on others: To men is allotted what they earn, and to women what they earn: But ask Allah of His bounty. For Allah hath full knowledge of all things. (4:32)

Table 3: A. H. M. Sadeq's understanding of factor pricing

\begin{tabular}{|l|l|}
\hline $\begin{array}{l}\text { Factor/ Re- } \\
\text { source }\end{array}$ & Pricing based on value-loaded guidelines \\
\hline Labour & $\begin{array}{l}\text { The element of humanity disables it to be treated as a sale- } \\
\text { able item. The consideration of ability, dependents and work } \\
\text { conditions in determining real wage. Market forces play a } \\
\text { secondary role in deciding upon the lower-limit. }\end{array}$ \\
\hline $\begin{array}{l}\text { Land/ Physical } \\
\text { Capital }\end{array}$ & $\begin{array}{l}\text { Allows for a fixed price or rental to be charged on all phys- } \\
\text { ical assets. Legitimate even if losses are incurred from the } \\
\text { economic activity as the contracted service has been utilized, } \\
\text { resulting in possible depreciation of the productive asset. }\end{array}$ \\
\hline Money capital & $\begin{array}{l}\text { The above analogy is not applicable for financial assets simply } \\
\text { because it does not lose its face value over time. Capital in the } \\
\text { form cash is treated as an investment and hence is entitled for } \\
\text { a predetermined profit sharing. }\end{array}$ \\
\hline Entrepreneurship & $\begin{array}{l}\text { Simultaneously decided with the price of money capital which } \\
\text { is a form of contribution towards a business venture. The } \\
\text { actual size of the price is post-determined, but the shares are } \\
\text { pre-determined. Ultimately, the amount of profits varies pro- } \\
\text { portionately with the risks taken and actual outcomes. }\end{array}$ \\
\hline
\end{tabular}


Basically, he proposes that in Islam, factors should be priced equitably and rewarded justly, to restrain the possibility of gross inequalities in income and wealth. According to Fahim Khan (1990), the conventional economic theory uses a particular classification of factors of production which is arbitrary and has no scientific sanctity attached to it. Consequently, attempts are being made to review and reformulate the theories of production and distribution in Islamic framework, in order to have our own directions to develop the theories of production and distribution. All permissive and prohibitive practices involving distribution in the production process leans towards achieving equitable outcomes. The underlying idea is that despite the distribution according to need based entitlements at the pre-production phase, equity is sustainable in the form of rights to earnings deriving from ownership of productive intangible resources such as capabilities, talents and marketable skills.

\section{STUDIES RELATED TO THE REDISTRIBUTIVE PHASE}

Under proper conditions, markets are good at allocating resources, but not at generating a distribution of income that reflects the conscience or the prevalent view of the society. Therefore, the government cannot abdicate this role but instead pursue its role differently. Zubair Hassan (2008) admits to the likelihood of markets to falter and fail society on many fronts, while agreeing to certain government intervention policies to adversely affect the allocation of resources and distribution of incomes. He adds that in principle, Islam stands for free markets requiring the government to merely oversee if the tenets of the Syariah are being observed in letter and spirit. Similar opinions are expressed in the writings of Abu Yusuf and Ibn Khaldun (Islahi, 1992). Islahi notes that Islam does not consider market mechanism as sacrosanct, although it encourages it in general. In other words, whenever market fails to achieve the objectives desired by Islam, the state shall use corrective measures following an institutional approach. Azizi Che Seman (2004) shares the general views of past Muslim scholars with regards to the justification of redistribution of wealth and income in Islam. Ibn Taymiyyah for example claimed that whoever is unable to earn sufficiently must be aided with money. He added that, if an obligation cannot be met without certain means, then the acquisition of these means becomes an obligation.

Interestingly, when requested by the Sultan to give a ruling in favour of imposing new taxes over and above Zakah, Imam Al-Nawawi (1223-77) refused to do so, unless the ruler himself surrendered all ornaments owned to Baitulmal and desisted from extravagance. Hence the standard of Islam is clear as to the preconditions of extraordinary State collections for the purpose of redistribution. 
At this juncture, it is necessary to remind ourselves that some inequality is an integral part of the Divine design. The Quran reiterates the objectives of differences in fortune and rizq to convey the wisdom of relative disparities in sustenance. The rich are tested on their abundance and the poor on their poverty. Thus, inequality is permissible and sometimes even necessary but not truly desirable. The Islamic ideology does not call for an artificial perfect equality but instead offers a range of tools to redistribute income and wealth to remove gross inequalities.

Being one among the five pillars, zakat is a form of worship and becomes an inevitable part of obeying God and it therefore has spiritual significance. "Of their wealth take alms so that, through it, you may purify and sanctify them..." (9:103). When the Prophet (SAW) sent Mu'ath to the people of Yemen, he told him: "And let them know that Allah has ordained on them alms, to be taken from their rich (people) and given to their poor..."

A thorough analysis of the sources related to zakat, leads us to conclude that the principle of distributive justice rooted in its rulings is the precedence of need. Equality is conditional upon sufficiency and availability of all the asnafs.

"Alms are for the poor, the needy, the employees who administer the funds, those whose hearts have been recently reconciled to the Truth, those in bondage, those in debt, in the cause of Allah, and the wayfarer, (thus it is) ordained by Allah, and Allah is most knowledgeable, most wise." (9:60)

Nearly all of the reknowned Islamic economists have assigned a crucial role to the state in a future Islamic economy and advocated that the state should redistribute income in favor of the poor, interfere in the markets when necessary, ensure the provision of basic necessities, and even, according to one economist, initiate massive land reforms.

Habib Ahmed (2004) in his lengthy occasional paper on the Role of Zakat and Awqaf in Poverty Alleviation reaffirms the significance of these traditional Islamic non- market institutions in promoting social welfare. Awqaf revenues can be increased by putting it into productive activities such as cash waqaf to be extended for microfinance purposes. In any case, the awqaf is expected to be distributed based on need and usage but monitored by the administrators to ensure the trust is carried out according the original request of the waqaf creator.

Other mechanisms of private distribution of wealth available in the Quran are infaq, sadaqah and qard.

"So fear Allah as much as you can; listen and obey, and spend in charity; that is better 
for you. And whosoever is saved from his own greed, they are the successful ones. If you lend to Allah a beautiful loan, He will double it for you and forgive you. (64:17)

Evidences from the Quran and Sunnah reiterate that the distribution of inheritance should be based on ones entitlement as prescribed by the Book of Allah, followed by the nearest male heir.

It is prescribed, when death approaches any of you, if he leave any goods that he make a bequest to parents and next of kin, according to reasonable usage; this is due from the Allah-fearing. (2:180)

In conclusion, distribution at the post-production phase in an Islamic economic framework is directed towards facilitating circulation of wealth to achieve equality in opportunity and establishing social security. The obligatory and auxiliary measures available within the system when implemented appropriately can in fact effectively meet the economic goals of distribution in Islam.

\section{METHODOLOGY}

In developing an Islamic framework that serves to describe the core principles of distributive justice in its general form, the research adopts a method introduced by Sekaran (2010) enabling the operationalization of a concept that reduces its abstraction and translate the concept of distributive justice into measurable elements.

These are the three steps suggested by the Sekaran in the process of converting a concept (distributive justice) into quantifiable terms in the context of economics:

1. Identifying a set of behavioural dimensions denoted by distributive justice. For example, the facets of rights, wealth circulation, social solidarity, etc as factors of justice in distribution.

2. Translating these dimensions into measurable elements. In the case of wealth circulation, a good yardstick is the mechanisms in place to reduce the disparity between groups.

3. Generating an appropriate response format that best represents the dimensions. The disbursement of zakat and size of waqaf funds as valid proxies of the flow of wealth from the surplus to the deprived economic agents within a community.

\section{THE DIMENSIONS OF EQUITY}

The revealed knowledge of Islam is replete with advocates for equity as a norm in upholding justice in all domains of one's life. The task of departmentalizing 
its role to any exclusive realm is inappropriate and hence pointless, for Islamic economics is adopts a holistic approach.

There are several dimensions of equity available in the Quran and Sunnah. However, since the purpose of this chapter is to demonstrate that it is indeed possible to develop a conceptual framework based upon Islamic heritage, the researcher will concentrate on the following five dimensions of distributive equity; rights, ownership, circulation of wealth, equal opportunity and social security. Keeping in mind that it is possible to change or alter or even reject (by a superior) an Islamic theory once an alternative theory is formulated in a particular social context.

\section{RIGHTS/HAQ}

Resources provided by nature and which can be used directly by man may be utilised freely, as everyone is entitled to benefit from them according to his needs. There is nothing to prevent individuals availing themselves of Allah's earth as long as they do not interfere with the rights of others or of the state. Conversely, it is unjust when things created by Allah for the benefit of mankind is taken possession of, and then kept idle and useless.

According to J. Badawi, the right to own property is an instinctive matter as it is related to survival and self-preservation. He adds that the nature of property rights depends on the type of ideology that is followed in any particular society and time. Islam acknowledges rights to property (ownership) as part of our responsibility as trustees of God on earth.

Know they not that Allah doth accept repentance from His votaries and receives their gifts of charity, and that Allah is verily He, the Oft-Returning, Most Merciful. (9:104)

Rifaat Hassan (2006) believes that the Qur'an is the Magna Carta of human rights and that a large part of its concern is to free human beings from the bondage of traditionalism, authoritarianism (religious, political, economic, or any other), tribalism, racism, sexism, slavery or anything else that prohibits or inhibits human beings from actualizing the Quranic vision of human destiny embodied in the classic proclamation:

“Towards Allah is thy limit." (53: 42).

From the perspective of the Qur'an, these rights came into existence when we did; they were created, as we were, by God in order that our human potential could be actualized. They not only provide us with an opportunity to develop all our inner resources, but also hold before us a vision of what God would like 
us to be: what He wants us to strive, live and die for. Rights created or given by God cannot be abolished by any temporal ruler or human agency. Eternal and immutable, they ought to be put into effect since everything that God does is for 'a just purpose.'

And in no wise covet those things in which Allah Hath bestowed His gifts More freely on some of you than on others: To men is allotted what they earn, and to women what they earn: But ask Allah of His bounty. For Allah hath full knowledge of all things. (4:32).

\section{OWNERSHIP}

A cardinal concept in the Qur'an underlying the socio-economic-political system of Islam is the ownership of everything belongs not to any person, but to God. Since He is the universal creator, every creature has the right to partake of what belongs to Him. Ownership rights in Islam originate from the concept of khilafah (stewardship), which is a constituent of the Islamic faith.

It is He who hath made you (His) vicegerents (or stewards), inheritors of the earth. He hath raised you in ranks, some above others; that He may try you in the gifts he hath given you." Hence, a person entrusted with wealth can achieve the highest degree of virtue (falâh) by spending out of his wealth within the boundaries prescribed by the sharîah. (6:165).

By implication, the ownership of al-mâl is understood to be a trust and its disposal is considered to be a test of faith since the owner has to use it in accordance with God's revealed wisdom. The Quran states:

Parable of those who spend their substance in the way of Allah is that of a grain of corn: it groweth seven ears, and each ear Hath a hundred grains. Allah giveth manifold increase to whom He pleaseth: And Allah careth for all and He knoweth all things. (2:261).

Through an examination of the divine rules (Ahkam Shariah) which allow man to possess property, it becomes apparent that the means of possession are limited to five which are work, inheritance, for the sake of survival State grants and transfers.

"And say: work; soon will God observe your work and His Apostle, and the Believers." (9:105).

"Concerning (the inheritance) for your children: to the male is the equivalent of the portion of two females, and if they (children) were women more than two, then theirs is two-thirds of the inheritance." (4: 11).

"And in their wealth there is a right acknowledged. For the beggar and the destitute."(70:2425).

And in their wealth there is acknowledged right for the needy and destitute. (51:19)

He who has killed a believer by mistake must set free a believing slave and pay the blood money to the family of the slain."(4: 92). 


\section{CIRCULATION OF WEALTH}

Two matters could lead to the maldistribution of wealth among people. The first would be to allow the circulation of wealth exclusively among the rich; and the second would be to deprive people from that wealth, and to prevent them from acquiring the means of circulation of that wealth.

Islam resolves these two possibilities by decreeing a host of Shariah rules designed to prevent hoarding (means of piling up money without a purpose) among the well offs.

"And let those who hoard gold and silver and do not spend them in the way of Allah know that a severe and painful punishment is awaiting them."(9:34).

The principles of moderation in consumption and spending steers the equity characteristic for wealth to flow from the surplus units to the rest.

Behold, ye are those invited to spend (ofyour substance) in the Way of Allah: But among you are some that are niggardly. But any who are niggardly are so at the expense of their own souls. But Allah is free of all wants, and it is ye that are needy. If ye turn back (from the Path), He will substitute in your stead another people; then they would not be like you! (47:38).

According to Yusoff $(2010,2012)$ the means of interpersonal distribution of income and wealth has favourable multiplier effect. Equity is the represented by the mode of resource mobilization through sharing and partnerships formed from the circulation of wealth.

Who is he that will loan to Allah a beautiful loan, which Allah will double unto his credit and multiply many times? It is Allah that giveth (you) Want or plenty, and to Him shall be your return. (2:245).

They ask thee what they should spend (In charity). Say: Whatever ye spend that is good, is for parents and kindred and orphans and those in want and for wayfarers. And whatever ye do that is good, -Allah knoweth it well. (2:215).

\section{EQUAL OPPORTUNITY}

The equity which Islam believes in is the equality of opportunity to secure a livelihood and desires that no obstacles should exist in society to prevent an individual from striving for a living according to his capacity and talents; nor should any social distinctions exist with the object of safeguarding the privileges of a certain class, race, dynasty or group of people. However, the concept of rizq plays a crucial role in seizing such opportunities. 
Allah doth enlarge, or grant by (strict) measure, the sustenance (which He giveth) to whomso He pleaseth. The wordly rejoice in the life of this world: But the life of this world is but little comfort in the Hereafter. (13:26).

Allah has not distributed His gifts and favour equally among mankind but, in His infinite wisdom, has given some individuals more than others.

See how We have bestowed more on some than on others; but verily the Hereafter is more in rank and gradation and more in excellence. (17:21).

The laws of society should neither be such as would establish a permanent monopoly for the owners of resources and make it impossible for the rest to acquire them nor such that the race for everyone should compulsorily begin from the same point and under the same conditions so that they would all be tied to each other right till the end of the race. On the contrary, economic laws should be such as to make it possible for all, who started his race under adverse conditions, to acquire resources, if he can do so by dint of his effort and ability, and for he who inherited them to be left behind in the race and to lose it, if he does not have the ability or efficiency to keep it.

\section{SOCIAL SECURITY}

What makes Islamic economics distinguished is that scarce resources may be allocated in many ways other than through exchange by the institutions of exchange. Under the integrative system, the Islamic concept of exchange is clearly not value-free. It has in fact, social and moral overtones. Islamic economics with both the provision of exchangeables as understood in modern economics and the non-changeables (i.e., transfer payment) which frequently takes place under the conditions of relative social concern and moral responsibility.

According to N.M. Ghifari (1979), the aims of the Islamic social security system includes a wider circulation of wealth, the prohibition of concentration of wealth and anti-social economic institutions, reduction of poverty, establishing a balance between individualism and collectivism, social justice (pay according to ability and paid based on needs), and restoring man's selfassertion and self-respect.

It is not righteousness that ye turn your faces Towards east or West; but it is righteousness- to believe in Allah and the Last Day, and the Angels, and the Book, and the Messengers; to spend of your substance, out of love for Him, for your kin, for orphans, for the needy, for the wayfarer, for those who ask, and for the ransom of slaves; to be steadfast 
in prayer, and practice regular charity; to fulfil the contracts which ye have made; and to be firm and patient, in pain (or suffering) and adversity, and throughout all periods of panic. Such are the people of truth, the Allah fearing.

Under the shade of the Islamic code, a non-Muslim individual's personal dignity, property and wealth are protected and secured whether he is under covenant or lives in peaceful co-existence.

"Allah does not forbid you from those who do not fight you because of religion and do not expel you from your homes - from being righteous toward them and acting justly toward them. Indeed, Allah loves those who act justly."(60:8).

From an Islamic point of view, social welfare is the greatest responsibility of the State. The various physiological and psychological needs are perceived as two sides of a coin. Meeting one is expected to at least motivate the fulfillment of the other. Logically, when the basic needs (material, interpersonal, security and esteem) are consistently met without struggle, the society as a whole stands a better chance to move ahead with self-actualization needs often echoed by achievements of truth, justice, beauty and creativity.

\section{FINDINGS}

When combined with the model of stages of distribution by production phases (Figure 3), all the 5 dimensions tend to converge into their respective positions. Equal opportunity and rights are essential means of dispensing equity at the pre-production phase in advancing the push for justice so central to Islam. Ownership in the form of work is core at the post production phase, for Islam rewards its believers based on their activities, especially ones which are beneficial. Circulation of wealth and social security become significant at the redistributive phase, aimed at reducing the inequalities brought about by market imperfections but rightfully the function of the State to establish justice.

The hypothetical framework of Distributive Justice below depicts the operationalization method adopted in this research. The abstract concept of distributive justice is converted into dimensions which then are converted into quantifiable elements. The boxes at the far right are meant to serve as a cross reference in designing socio-economic policies. 


\section{Conclusion}

Figure 3

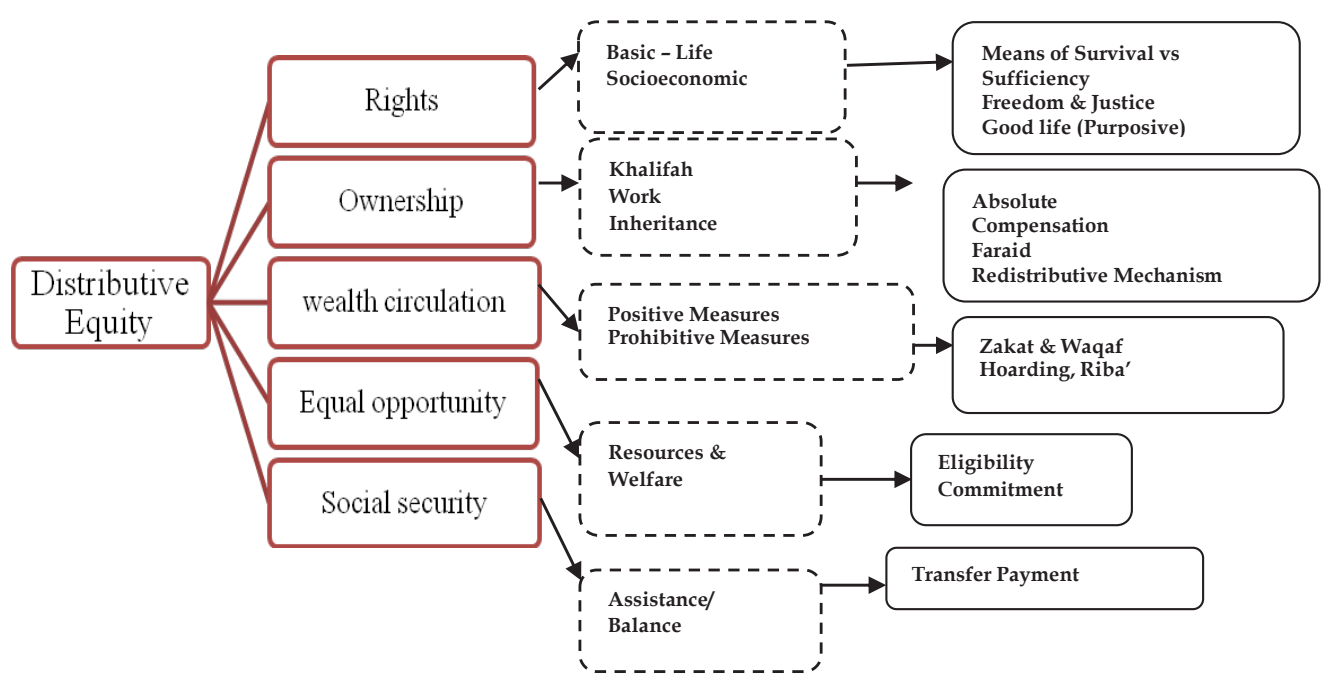

Hypothetical framework above is the amalgamation of distributional justice in the 3 stages of production and the dimensional meachanisms of distributive equity as discussed and elaborated in the earlier sections.

From an Islamic economics perspective, all the standards of distribution identified and accepted by the counterpart are valid, but is valued differently. Related studies by Muslim economists in particular clearly illustrate that the significance of each principle changes concurrently with the objective of a given economic distribution. Incidentally, the stage of distribution along the production process determines the ultimate/ real purpose of the given distribution. Assuming we agree with and accept the three goals distributive justice established by Iqbal, $M$. the sole principle that emerges from the guaranteeing of fulfillment of basic needs, equitable personal incomes and elimination of extreme inequalities achievement of equal opportunity, is EQUITY.

All critical literature reviews in the previous chapter and the evidences from the Turath analyzed in this chapter resulted in the five criteria of a conceptual framework of distributive justice purely based on Islamic tenets. They collectively point towards istihsan (the nearest Islamic law doctrine to the notion of equity in western jurisprudence). Once this notion is casted upon economics in general and distribution in particular, adl' and ihsan appears to be defining characters of distributive justice in Islam. 


\section{REFERENCES}

A.H.M. Sadeq., 1989. "Factor Pricing and Income Distribution From an Islamic Perspective." Journal of Islamic Economics, Vol. 2, No.1, pp. 4553.

Abdel Hamid El-Ghazali.,1994. "Man is the Basis of Islamic Strategy for Economic Development." Islamic Economics Translation Series. No.1 by IRTI.

Abdul Azim Islahi., 2004. Contributions of Muslim Scholars to Economic Thought Analysis (11-905 A.H./632-1500 A.D.). Islamic Economic Research Center, King Abdul Aziz University, Jeddah, Saudi Arabia.

Ahmed, Habib.,2004. Role of Zakat and Awkaf in Poverty Alleviation. IDB (IRTI). Occasional Paper. No.8.

Azizi Che Seman \& Nor Aini Ali., 2004. "Economic Thoughts of Redistribution of Income dan Wealth: A Comparative Analysis." Shariah Journal, $12: 2$, pp. 25-42.

English-Quran with commentaries by Yusuf Ali: The Meaning of The Noble Quran., 2006. (source: http://www.pdf-koran.com/Koran.pdf).

Fleurbaey, M., 2012. Economics and Economic Justice, The Stanford Encyclopedia of Philosophy (Summer 2012 Edition), Edward N. Zalta (ed.).

Haneef, M. A., 1995. Contemporary Islamic Economic Thought: A selected Comparative Analysis. Kuala Lumpur: Ikraq.

Islahi, A. A., 1993. "Islamic Distributive Scheme: A Concise Statement." Journal of Objective Studies. Vol.5, No. 1. 98-111.

Khaliq Ahmad \& Arif Hassan., 2000. "Distributive Justice: The Islamic Perspective." Intellectual Discourse, Vol 8, No 2, 159-172.

Mannan, M. A., 1984. The Frontiers of Islamic Economics: Some Philosophical Underpinnings.

M. Fahim Khan., 1990. "Factors of Production and Factor Markets in Islamic Framework." JKAU: Islamic Econ, Vol. 2, pg. 25-46. (Source: http:// www.kau.edu.sa/Files/320/Researches/51020_21157.pdf).

M. N. Siddiqi, 1986. Guaranteeing a Minimum Level of Living in an Islamic State. In Distributive Justice and Need Fulfilment in an Islamic Econo$m y$, ed. by Munawar Iqbal. Islamabad: International Institute of Islamic Economics.

M. Quraish Shihab., 1996. Wawasan Al-Quran: Tafsir Tematik atas Pelbagai Persoalan Umat

M. Umer Chapra., 1992. “Islam and the Economic Challenge." Islamic Economics Series - 17. The Islamic Foundation The International institute of Islamic Thought. 
M. Umer Chapra., 2007. Guarantee of Satisfaction of Fundamental Needs. Encyclopedia of Islamic Economics.

Mabid Ali Al- Jarhi., 1985. “Towards an Islamic Macro Model of Distribution: A Comparative Approach." JRIE, Vol. 2, No. 2, pg. 3-29.

Majid Khadduri., 2001. The Islamic Conception of Justice. Publisher JHU Press (reprint).

Monzer Kahf., 2002. "Allocation of Outputs to Factors of Production and the Implicit Islamic concept of Market Justice." Seminar on the Theory of Functional Distribution of Income, Lawrence, Kansas. Organized by IRTI.

Noor Mohammad Ghifari., 1982. Social Secury System in Islam. PhD Thesis. Punjab University, Lahore.

Siddidui, Nejatullah., 1988. Role of the State in the Economy The Islamic Foundation, Leicester, U.K.pp. 255.

Zubair Hasan., 1988. Distributional equity in Islam. Published in: Munawar Iqbal ( Ed.): Distributive justice and need fulfillment in an Islamic Economy (1988): pp. 35-62.

Zubair Hasan., 2008. "Markets and the role of government in an economy from Islamic perspective." (Source: http:// http://mpra.ub.uni-muenchen. de/12233/) 